\title{
Lead Measurement
}

National Cancer Institute

\section{Source}

National Cancer Institute. Lead Measurement. NCI Thesaurus. Code C147382.

The determination of the amount of lead present in a sample. 